Revista de DeRecho UNED, NÚM. 12, 2013

\title{
LA PRECARIEDAD EN SU VOLUNTARIEDAD: LAS SOCIEDADES DE SOCORROS MUTUOS EN EL PRIMER LIBERALISMO A PROPÓSITO DE LOS MONTEPÍOS DE ABOGADOS
}

THE PRECARIOUSNESS OF VOLUNTARY CONTRIBUTIONS TO FUNDS. THE CASE OF MUTUAL ASSISTANCE SOCIETIES IN THE FIRST WAVE OF LIBERALISM IN RELATION TO WIDOWS' AND ORPHANS' FUNDS SET UP BY LAWYERS

\author{
Carlos Tormo Camallonga \\ Universitat de València-Estudi General
}

Resumen: El reglamento del Montepío del Colegio de Abogados de Valencia de 1825 nadará entre el proteccionismo corporativista del Antiguo Régimen y el pragmatismo economicista de la Ilustración, para adaptarse, más tarde, al individualismo y el mercantilismo del Liberalismo. El trato hacia viudas y huérfanos no podía ser el mismo, lo que exigía un cambio de actitud disconforme con el sentir de muchos abogados. Y aunque la reforma de las mutualidades es paralela a la de gremios y colegios profesionales, el trato dispensado por la Administración será distinto, pues diferente era el interés del Estado en unas y otras corporaciones. Frente a los beneficios económicos privativos, el interés público por regular una profesión, la abogacía y, por extensión, el mundo del Derecho, llamado a dirigir la transformación política del sistema.

Palabras clave: Montepío, socorros, pensión, viudedad, orfandad

Abstract: The regulation of the widows' and orphans' fund of the bar of Valencia in 1825 was characterised both by corporate values of the Old Regime and the economic pragmatism of the Illustration; it later adapted to the individualism and commercialism of 
burgeoning liberalism. With regard to the treatment of widows and orphans, an adjustment was made in the light of the new liberal mentality. The subsequent reform of the mutual assistance societies was parallel to the changes that took place at trade unions and professional collegiate bodies. However, the administration treated the orphans' and widows' funds differently, as there were different interests at stake in each corporate body. There was competition between the exclusive interests of their individual members and the public interest to regulate a profession; the legal profession called for a direct political transformation of the system.

Keywords: Widows' and orphans' fund, assistance, pension, widowhood, orphanhood

Recepción original: 09/05/2013

Aceptación original: 10/05/2013

Sumario: I. Introducción. II. La Junta. III. Los individuos del Montepío. IV. Ingresos. V. Socorros. 1. Pensiones y socorros de abogados. 2. Pensiones de viudas y pupilos. 3. Cese de la pensión de viudedad y orfandad. 4. Huérfanas. VI. Las lagunas del nuevo reglamento. VII. Eventual equilibrio presupuestario. VIII. Consideraciones finales.

\section{INTRODUCCIÓN}

Se dice que en España ha sido poca la atención que la historiografía ha prestado a las sociedades de socorros mutuos ${ }^{1}$. Y, aunque en los últimos años han sido notables los avances, especialmente para gremios, cofradías y mutualismo laboral en el XIX, la bibliografía sobre los montepíos sigue siendo muy escasa. La mayoría de los estudios se centran en la nueva realidad que nace de los decretos de 8 de junio de 1813 y 20 de enero de 1834, así como de la ley de 6 de diciembre de 1836; normas que, aunque no suprimían los gremios, suponían la extinción de sus prerrogativas esenciales como instituciones reguladoras del ejercicio profesional ${ }^{2}$.

1 CASTILLO, S., "Las sociedades de socorros mutuos en la España contemporánea», Solidaridad desde Abajo. Trabajadores y Socorros Mutuos en la España Contemporánea, Unión General de Trabajadores. Centro de Estudios Históricos, Madrid, 1994, págs. 1-29.

2 Colección de los decretos y órdenes que han expedido las cortes generales y extraordinarias, IV, Madrid, 1920, pág. 86; Decretos de la reina nuestra señora doña Isabel II, XIX, Madrid, 1835, págs. 26-28; y Decretos de la reina doña Isabel II, XXI, Madrid, 1837, pág. 563; respectivamente. Véase YBORRA LIMORTE, J.A., «El decre- 
En estas páginas partiremos de la real orden del Consejo de Castilla de 27 de julio de 1767, por la que se imponía la transformación de todas las cofradías y hermandades de socorros en montepíos, bajo pena de desaparición. Dicha transformación se operaba con la aprobación por el Consejo de sus nuevas ordenanzas, que debían contener, necesariamente, la reducción de sus gastos religiosos a una misa anual. Con ello se buscaba reforzar el auxilio y la previsión, mediante la reducción de los gastos religiosos al mínimo. Paralelamente, se perseguía una menor dependencia de la Iglesia y un mayor control por parte del poder real, así como su sometimiento a la jurisdicción real $^{3}$. Todo ello muy acorde con el reformismo borbónico del momento. Y, si en un principio el socorro o la ayuda mutua era propio, más que nada, de las clases populares, las reformas del trabajo llevadas a cabo por los ilustrados del XVIII, contemplaban la fundación de montepíos también para los sectores con mayores rentas.

Pero la realidad no colmó, ni de lejos, las expectativas. Desde la calamitosa situación en que se encontraban a finales del siglo XVIII, sin un decidido impulso oficial o, lo que es lo mismo, sin una regulación legal y con sólo sus estatutos, la mayoría de montepíos privados estaban abocados al fracaso ${ }^{4}$. El individualismo a ultranza y el abstencionismo del primer liberalismo, cuando no indiferencia, no harán sino agudizar esta situación. Lo comprobamos en los montepíos de abogados, cuya vida, salvo alguna excepción, languidecía a pesar de las reformas que continuamente eran introducidas, todas ellas encaminadas a evitar la apatía y el desentendimiento generalizados entre sus individuos.

En paralelo a la decadencia de la vida mutualista, tampoco los propios colegios de abogados vivían sus mejores horas. Por decreto de cortes de 8 de junio de 1823, se suprimía para abogados, médicos y demás profesores aprobados, la adscripción obligatoria a cualquier colegio o corporación para ejercer. Y aunque la norma no tuvo efecto alguno por la inmediata vuelta de los absolutistas, sí lo tuvo

to CCLXII, de 8 de junio de 1812, sobre la libertad de industria, oficio y trabajo», El legado de las cortes de Cádiz, coords. Pilar García Trobat y Remedio Sánchez Férriz, Valencia, 2011, págs. 375-389.

3 ÁVALOS MUÑOZ, L.M. y SANZ VALDÉS, J., «Las mutualidades de previsión social: antecedentes, situación actual y perspectivas», Solidaridad desde Abajo..., págs. 541-567.

4 RUMEU DE ARMAS, A., Historia de la Previsión Social en España. CofradíasGremios-Hermandades-Montepios, Revista de Derecho Privado, Barcelona, 1981, págs. 416 y 463 y ss. 
cuando se repuso en 1837, por decreto de 11 de julio ${ }^{5}$. Es el liberalismo que consagra el dogma de la libre voluntad del individuo y su autonomía decisoria, desdeñando todo tipo de sociedades que se pudieran interponer entre ellos y entre el individuo y el Estado. Es una regulación en la línea marcada por los referidos decretos de 8 de junio de 1813, 20 de enero de 1834 y 6 de diciembre de 1836, que proclamaban la libertad de establecimiento y extinguían todo tipo de privilegios de que hasta el momento habían disfrutado los gremios. Estamos ante el presupuesto y el resultado de lo que se estaba gestando ideológicamente y se esperaba, también, desde los nuevos postulados económicos.

Pero, vistas, o previstas, las consecuencias del decreto de 11 de julio de $1837^{6}$, por otro de 28 de mayo del año siguiente se publicaron los Estatutos para el régimen de los Colegios de Abogados del Reino, que de nuevo vinieron a modificar el régimen asociativo colegial y mutualista. La aprobación de estos Estatutos quería presentarse como el inicio de una nueva etapa y el final de un orden corporativista que se tenía por desfasado; la definitiva entrada en el régimen constitucional de libertades, tanto para el ejercicio de las profesiones liberales, en este caso la abogacía, como de sus colegios, así como de las sociedades de socorros mutuos que en su seno se habían creado. Sin embargo, estas libertades no fueron completas. Si el artículo 36 de los Estatutos daba por extinguidos los antiguos montepíos forzosos, el 1 exigía para abogar, otra vez y entre otros requisitos, la incorporación en la matrícula del colegio de abogados allí donde existiera ${ }^{7}$. Así pues, mientras que la libertad de ejercicio sin necesidad de colegiación no llegó a ser posible ni siquiera durante un año, la obligatoriedad en el ingreso en el montepío fue suprimida definitivamente, limitándose el gobierno poco más que a «invitar» a los abogados a formar asociaciones de socorros mutuos. Frente a la conveniencia pública y social alegada por muchos mutualistas, la nueva administración apostaba por el

5 ESCRICHE, J., Diccionario razonado de legislación y jurisprudencia, 3 edición, 2 vols., Madrid, 1847, I, pág. 23. Para los abogados véase el real decreto precedente de 22 de abril de 1811 en TORMO CAMALLONGA, C., "Derechos individuales, derechos corporativos: el decreto de 22 de abril de 1811», El legado de las cortes de Cádiz..., págs. 433-454.

6 Especialmente por lo que respecta a la distribución de las causas de pobres, en que los colegiados se sentían agraviados por ser ellos quienes las tenían que soportar todas.

Véase un estudio de estos estatutos en TORMO CAMALLONGA, C., «El Col. legi d'Advocats de Sueca», VII Assemblea d'Història de la Ribera, Sumacàrcer (Valencia), 1998, en prensa. 
libre arbitrio del individuo. Obviamente, el interés que podía tener el gobierno era bien diferente en un caso y en el otro: si la mutualidad entraba en el campo de lo privado, la abogacía lo hacía en el de la res publica. Recuérdese que es ésta la gran profesión de los nuevos tiempos; letrados serán los legisladores, políticos y juristas llamados a construir el nuevo orden. Ningún gobierno escapaba al atractivo de vigilar y fiscalizar semejante ministerio, y ello pasaba, en primer lugar, por establecer una organización unificada para todas sus agrupaciones.

Es en este contexto histórico-jurídico de interesada hostilidad, según el caso, hacia las corporaciones profesionales liberales, en donde situamos al montepío del colegio de abogados de Valencia en el presente estudio, apuntalado entre su reglamento de 1825 y los Estatutos de los Colegios de 1838.

El primitivo reglamento del Montepío había sido aprobado por real provisión del Consejo de Castilla de 20 de marzo de 1778, siendo una copia, con ligeras modificaciones, del de Madrid de 31 de agosto de $1776^{8}$. Si, por falta de fondos, la actividad del montepío de Madrid fue consumiéndose año tras año, no podemos esperar que ocurriera cosa muy diferente para el de Valencia $^{9} \mathrm{Si}$ el primer reglamento del Montepío de la corte fue substituido por otro de 14 de febrero de 1807, el valenciano correría igual suerte, con una nueva ordenación aprobada por auto del Consejo de 11 de marzo de 1825, expedido por provisión de 21 de marzo. Otra vez el reglamento del montepío de Valencia iba a ser una copia, con ligeros retoques, del de Madrid. Tampoco resulta extraño si consideramos que la provisión del Consejo de 14 de diciembre de 1761, por el que se aprobaban los estatutos del colegio valenciano, concedía y autorizaba la incorporación por filiación de este colegio al de la corte, al tiempo que declaraba que todos los decretos, autos acordados y providencias promulgadas y expedidas a favor de éste -entre ellos, los propios estatutos- se entendían extensibles al de Valencia, del mismo modo que si para él se hubiesen librado.

8 TORMO CAMALlONGA, C., «El Montepío del Colegio de Abogados de Valencia», Boletín de la Facultad de Derecho, 19 (2002), 15-75. Puede verse una copia del reglamento de Madrid de 1778 en Archivo del Ilustre Colegio de Abogados de Valencia (en adelante, AICAV), caja 387.

9 Sobre el Montepío de Madrid véase BARBADILLO DELGADO, P., Historia del Ilustre Colegio de Abogados de Madrid, 3 vols., Madrid, 1956-60, II, págs. 161-168, y III, págs. 119-121. 
Los últimos años de los primitivos estatutos del montepío valenciano los podemos resumir con la idea de que, a la permanente situación de penuria, se añadía la confusión ocasionada por la Guerra del Francés. Los retrasos de sus individuos en el pago de las tercias se acumulaban todavía más de lo que, ya de por sí, era habitual. Y, por lo mismo, también se retrasaba aún más el pago de las pensiones de viudedad, que era, prácticamente, el único pago del que no podía librarse el Montepío, aunque el importe de las mismas se hubiera reducido constante y considerablemente.

Así pues, ante la presión y el descontento general de las viudas con derecho a pensión por el continuo y alargado retraso en su cobro, el 21 de febrero de 1824 el decano del Colegio comunicaba a la Junta del Montepío la necesidad de mejorar -o sea, aumentar- los fondos con que atender a las pensiones. En la junta de 6 de marzo de 1824, el decano expuso que se podían seguir dos caminos: o bien proponer al Consejo algunos arbitrios, como lo hizo el colegio de la corte, o bien solicitar del mismo tribunal que el nuevo reglamento de este colegio se aplicara también al de Valencia, en virtud del referido decreto de 14 de diciembre de 1761. La Junta se decantó por la segunda opción en la medida en que la primera supondría la formación de un expediente instructivo largo y costoso, en el que constara un estado de todos los ingresos e inversiones, como lo hizo en su momento el colegio de Madrid, a lo que en nada ayudaría el complejo registro de las cuentas, temerosos, además, de que se les pudiera recriminar cualquier falta de diligencia en el recaudo -no parece que fuera el caso $^{10}$.

En la misma junta del Montepío de 6 de marzo de 1824, el decano presentó el reglamento del Montepío de Madrid que, leído, pareció conforme a los miembros de la Junta, a excepción del capítulo quinto, dedicado a los fondos. Se discutió si los arbitrios que contenía podían ser oportunos también para Valencia. Tras concluir afirmativamente, la Junta realizará algunas reformas y adaptaciones, todas ellas referidas a las entradas. Las diferencias entre ambos quedaron como exponemos:

PRIMERA: Que en vez de los ochenta reales del tercio de contribución ordinaria, prevenidos en el § $2 .^{\circ}$ del capítulo $\mathrm{V}$, sean solamente cuarenta, que es la señalada en el reglamento antiguo.

10 AICAV, libro 3, Libro de Deliberaciones, juntas de 14 y 28 de julio de 1824, y libro 8, Libro de Acuerdos de la Junta del Montepio, juntas de 21 de febrero y 6 y 27 de marzo de 1824. 
SEGUNDA: Que los veinte y cuatro reales, como honorario de todas las conclusiones que los individuos pongan en los pleytos que defienden, sea para difinitiva o para artículos o incidentes en cualesquiera tribunales o juzgados de esta ciudad de Valencia, prefijados en el § 3. ${ }^{\circ}$ de dicho capítulo V, queden regulados a cuatro.

TERCERA: Que en lugar de la cuarta parte del honorario de las cuentas y particiones de herencias y bienes en que intervengan abogados por nombramiento judicial, o de las partes por avenencia extrajudicial, o por disposición de los testadores, prevenida en el $\S 4 .^{\circ}$ del mismo capítulo, se substituyan solos treinta reales vellón ${ }^{11}$.

Según consta en el acta de esta junta, los demás arbitrios contenidos en los párrafos sexto y siguientes de este capítulo no se estimaron necesarios para el montepío de Valencia. Sin embargo, esta salvedad no se recoge en la carta remitida por la Junta del Montepío al Consejo, tal y como consta en la provisión de 21 de marzo de 1825 , por la que se aprueba el nuevo reglamento, ni tampoco se recoge en esta misma norma ${ }^{12}$. Debemos entender, por lo tanto, que no quedaron suprimidos, al menos inicialmente ${ }^{13}$. En este sentido, en junta de 11 de julio de este año se acordó lo siguiente:

Que sin embargo de lo dispuesto en el párrafo $6 .^{\circ}$ Capítulo $5 .^{\circ}$ de la Real Provisión del Supremo Consejo, en la que se halla inserto el reglamento para el govierno del Monte-Pío del Colegio de Abogados, queda suprimido, por lo que se dispone en el párrafo $5{ }^{\circ}$ Capítulo 10 de dicho reglamento, por haverle parecido a la Junta muy gravosa la condición impuesta en dicho párrafo $6 .{ }^{014}$.

Según esta última disposición, los abogados que ingresaban en el Colegio superados los 26 años de edad debían pagar, además de la cuota de entrada, todas las tercias ordinarias devengadas desde los 26 hasta la edad de su incorporación, sin que estos pagos contasen como de residencia efectiva en el Colegio para adquirir derecho a sus beneficios. Pero el párrafo $5 .^{\circ}$ del capítulo X permitía a la Junta «añadir, reformar o corregir algo de lo establecido en este Reglamento", siempre que fuera conveniente, "con calidad de hacerlo presente al Consejo, y obtener la Real aprobación correspondiente

11 AICAV, caja 387, Real Provisión del Supremo Consejo..., legajo sin número, pág. 4.

12 Puede verse la real provisión y el reglamento en AICAV, caja 387, legajo sin número. Su título completo es: Real Provisión del Supremo Consejo por la que se manda, se entienda para con los abogados del colegio de esta ciudad el reglamento inserto para el gobierno de su Monte Pío, en los mismos términos que el de la Corte, bajo las modificaciones que se expresan. Con licencia: Valencia y oficina de D. Benito Monfort, año 1825.

13 Archivo del Reino de Valencia, Real Acuerdo, libro 120, folios 34 y 633-640v.

14 AICAV, libro 8, pág. $179 \mathrm{v}$. 
en los casos que lo exijan». Es probable que, interpretando si el caso exigía la aprobación del Consejo, la Junta opinara que no, pues ni siquiera solicita dicha aprobación. A la misma conclusión parece llegar la Junta, cuando subió la cantidad que se debía cotizar por las conclusiones de los 4 a los 10 reales vellón, como después veremos. En cualquier caso, visto está que la diferencia en las obligaciones de los afiliados en uno y otro montepío es más que sustancial, al menos al inicio. Y decimos esto porque, a partir del ejercicio contable de 1832-1833, sí que aparecerán registrados estos incrementos en la cuota de los incorporados mayores de 26 años, lo que se tradujo en sustanciosos aumentos del cargo anual de los inmediatos ejercicios contables.

En otro orden de cosas, y para terminar esta introducción, tenemos que decir que, de la misma manera que había sucedido con los estatutos del colegio, en que en numerosas ocasiones la Junta de Valencia tuvo que preguntar a la de Madrid por el sentido de alguna de sus cláusulas, la junta del montepío valenciano también acudirá a la madrileña para aclarar algún punto del nuevo reglamento. En otras ocasiones la Junta -también los tribunales- irá resolviendo las dudas conforme vayan surgiendo, y no siempre de una manera muy coherente con la letra del reglamento o con otros acuerdos anteriores, pero sí de las circunstancias del momento.

\section{LA JUNTA}

La Junta del Montepío, que era la propia del Colegio, estaba formada, en esencia, por sus mismos miembros: el decano, los cuatro diputados, el maestro de ceremonias, el tesorero, el secretariocelador -este oficio sí era propio y diferente del del Colegio- y el contador. En el reglamento de 1778 este último cargo recaía en el secretario del Colegio, pero con los estatutos de 1825, y para conseguir una mejor separación de los fondos del Colegio, pasará a ser un oficio independiente. Ambas juntas se elegían al mismo tiempo y, según los estatutos del Colegio, el 28 de agosto. Tomando posesión los cargos entrantes se iniciaba el nuevo año económico.

La principal función de la Junta era decidir la concesión o denegación de las pensiones solicitadas, esencialmente viudedad y orfandad, así como el libramiento efectivo de las mismas, si los fondos del Montepío lo permitían. Era una decisión que se adoptaba al vencimiento de cada una de las tres tercias anuales, que se libraban en los meses de mayo, septiembre y enero -esta última solía librarse 
para las navidades-. Pero en junta de 20 de febrero de 1839 se acuerda, a solicitud del decano, que fuera él mismo quien procediera por cuenta propia a expedir los libramientos, sin necesidad de convocar a la Junta de no haber otros temas a tratar. De hecho, ya lo había hecho con la última tercia del año anterior. Después daría cuenta de los libramientos en la siguiente junta ${ }^{15}$. Además del decano, los otros miembros de la Junta con funciones particulares eran el secretario, el contador, el tesorero y los conocidos como protectores.

El secretario daba cuenta de todas las instancias y expedientes relativos al Montepío, extendía los acuerdos, providencias y oficios que resultasen, así como las certificaciones, siempre bajo orden de la Junta o del decano. Como celador, debía cuidar de la puntual y exacta observancia del reglamento. Para todo ello tendría en su poder tres libros: el de los acuerdos de la Junta, el de los individuos contribuyentes y sus fallecimientos, y el de los pagos y pensiones.

En cuanto al contador, su principal función era llevar la razón de las entradas y salidas de caudales, y redactar las oportunas liquidaciones de los pensionistas. Para ello tendría otros tres libros: el de entradas, el de salidas y el de gobierno de la contaduría. En este último constarían todas las noticias de cada individuo desde su ingreso en el Colegio hasta su fallecimiento: licencia para casarse, ausencias o colocaciones. También debía llevar la cuenta del papel sellado para las conclusiones de los pleitos.

El tesorero, por su parte, debía recibir los caudales, firmar los recibos, con la prevención de tomar razón la contaduría, y satisfacer todos los que la Junta expidiera contra él, y fuesen firmados por el decano y el secretario e intervenidos por el contador. Para ello tenía dos libros: el de cargo, o entradas, y el de data, o salidas.

Entre los oficiales de la Junta se repartía la protección de las viudas y pupilos, «según dictaren las circunstancias y la mayor comodidad de los protegidos, a quienes ofrecerán todos los oficios de amparo y protección y prevendrán el modo de pedir la pensión» (cap. 6, 2). De ahí que se les llamase protectores. Se trata de un cargo propio y específico del Montepío, que recaía en el decano y los cuatro diputados, y cuya función era tramitar los memoria-

15 En la tercia de julio de 1839 parece que se excedió en esta delegación, cuando, además de ordenar los libramientos, reconoce la totalidad de una pensión en favor de Petra López, única heredera de su difunta madre viuda. De ello dio cuenta en la siguiente junta, razonando que la había concedido atendida la claridad del supuesto, a lo que la Junta, viendo efectivamente que así era, nada alegó; AICAV, libro 8, juntas de 20 de febrero y 19 de julio de 1839. 
les en los que las viudas o pupilos solicitaban auxilio o pensión. Puesto que en ninguna junta se acordaron reglas sobre el referido reparto, se entendía que continuaba vigente el que existía hasta entonces, ya que la provisión que aprobaba el nuevo reglamento le otorgaba el carácter de adicional, es decir, que en defecto de la nueva regulación se aplicaría la antigua. El decano se encargaría de los memoriales de las viudas y huérfanos de los abogados que hubieran ascendido al ministerio o a otro empleo honorífico por cualquier carrera, o hubiesen sido promovidos al estado eclesiástico. El diputado primero sería el protector de las viudas y pupilos de los abogados que hubieran sido decanos del Colegio; el segundo de las viudas y pupilos de los que hubieran sido oficiales de Junta, sin haber llegado al decanato; el tercero lo sería de las viudas y pupilos de los que hubieran sido examinadores o abogados de pobres; y el cuarto de las viudas y pupilos de los que nunca hubieran sido elegidos para ninguno de los cargos referidos. Tan pronto tenían noticia de la muerte de algún abogado, los protectores ofrecían a los posibles beneficiarios todos los oficios de protección y amparo, y les requerían para que, si lo pretendían, les entregasen un memorial solicitando la oportuna pensión. No obstante, lo habitual era que fueran las propias viudas las que presentaban directa y personalmente la solicitud. Concedida la pensión o auxilio, el protector debía remitir al decano, cada cuatro meses, una relación de las pensiones correspondientes a la clase de abogados de la que estaba encargado. Además, debía vigilar si sucedía cualquier supuesto que pudiera alterar o poner fin a su percepción, como la muerte o si alcanzaban la edad prefijada, profesaban en religión o se casaban. En todos estos procesos el protector gozaba de poder suficiente, que le habrían otorgado los interesados, para la cobranza de las pensiones, a no ser que los beneficiados designaran otro apoderado distinto o decidieran cobrarlas personalmente.

\section{LOS INDIVIDUOS DEL MONTEPÍO}

Aunque eran los abogados colegiados los que estaban llamados a ser los individuos del Montepío, resulta más interesante plantearnos, al revés, hasta qué punto la pertenencia al Montepío era efectivamente obligatoria para aparecer en la lista anual de individuos del Colegio y poder, así, ejercer como tales. La respuesta está íntimamente relacionada con la buena salud o la decadencia del Montepío. 
Según los antiguos estatutos, el ingreso en la sociedad era voluntario para los abogados ya incorporados en el Colegio en el momento de la fundación del Montepío, pero obligatorio para los que se incorporaran en adelante. Para cualquiera de ellos el impago reiterado de las cuotas suponía la expulsión del Montepío, bajo la amenaza de su expulsión también del Colegio. Sin embargo, y a pesar de reiterados acuerdos en parecido sentido, lo bien cierto es que las expulsiones sólo se llevaron a cabo respecto al Montepío. La Junta del Colegio no expulsó a ninguno de sus individuos por aquellos impagos. Es más, cualquier individuo podía reingresar al Montepío con el reintegro o el compromiso de reintegro de lo adeudado. Y, como ya hemos referido, y especialmente tras las calamidades de la Guerra, era difícil conocer si los abogados que no habían manifestado expresamente su voluntad de abandonar el Montepío, eran o no simplemente morosos. Para el caso de serlo, se les podía exigir el pago de lo adeudado, que pasaba a ser activo del Montepío, pero, y puesto que dependía de su voluntad el continuar o no en la sociedad, al que no pagaba no se le podía considerar necesariamente como deudor obligado. Ante una demanda presentada por las viudas para el cobro de sus derechos en 1818, la Junta del Montepío respondía al Real Acuerdo que ni ella misma conocía la suma exacta de lo que debían sus individuos, ya que ni siquiera conocía cuántos eran los deudores. En 1828 se descubre una liquidación de atrasos realizada en 1819 por el tesorero de aquel entonces, que actualizaba la información relativa a los pagos efectuados y pendientes de cada uno de los abogados. De los 84 abogados que habían ingresado en el Colegio y Montepío desde 1810, tan sólo dos habían pagado las tres tercias de contribución de entrada. A mediados de 1824, el Montepío tan sólo contaba con 9 contribuyentes, de alrededor de 115 colegiales $^{16}$. La situación no podía ser peor. Quedaba claro que, frente al déficit crónico y la total confusión que amenazaban la subsistencia de la sociedad, se imponía una reforma.

Pero en el nuevo reglamento no se dirá en ningún momento que la pertenencia al Montepío fuera obligatoria, ni siquiera con el solo objetivo de poder aparecer en la lista de individuos del Colegio, más allá, eso sí, del ingreso automático que llevaba aparejado cuando se ingresaba en éste, y el pago de la cuota de entrada y de la primera ordinaria. Exactamente lo mismo que con la anterior regulación, aunque en estos momentos estaba más claro que la continuación en la sociedad quedaba al entero arbitrio de los abogados. Suprimido

\footnotetext{
16 TORMO CAMALlONGA, C., «El Montepío del Colegio..., págs. 59 y ss.
} 
el régimen constitucional años atrás, parece que habían calando ciertas ideas liberales en materia corporativa. Eso sí, se continuaba sin saber si los que no pagaban eran simples morosos o se habían separado libremente de la sociedad; de ahí los continuos oficios de la Junta ${ }^{17}$.

Con el reglamento de 1825, las bajas en la sociedad se producían por fallecimiento, abandono voluntario o expulsión, teniendo las causas de esta última un carácter netamente sancionador o punitivo. En cuanto al carácter sancionador, por el párrafo $9 .^{\circ}$ del capítulo V se excluía a viudas y huérfanos de todo individuo que a su muerte quedara debiendo nueve tercias, o sea, tres años de contribución ordinaria, sin posibilidad de excusa alguna. El párrafo anterior recogía un supuesto de expulsión que podía tener cierta relevancia en el colegio de la corte, pero apenas en Valencia: el de los que marchaban a ocupar empleo en ultramar sin haber pagado su adeudo un año más al tiempo de su partida, y no dejaban persona encargada de ingresar los pagos sucesivos a su debido tiempo. En cuanto al carácter punitivo, sólo contamos con un caso, pero acordado por la Audiencia: el 13 de enero de 1826 privaba perpetuamente a José Gregorio Genovés de la facultad de abogar, por sus «demasías e inobediencias a las providencias de la sala» ${ }^{18}$. La expulsión de la abogacía llevaba pareja la del Colegio y, por supuesto, del Montepío, sin derecho a pensión alguna ni a recobrar las cantidades invertidas ${ }^{19}$. La dependencia de éste respecto a aquél continuaba siendo absoluta.

17 „Para asegurar su pago hay decretadas dos clases de contribuciones, una que pesa sobre todos los abogados, ya quieran o no disfrutar de los beneficios del Monte, y estos son los 1.500 rs. de entrada, los 120 por cada año que escedan a los 26 de edad los que hayan de ser admitidos; y otra que sólo se satisface por los que pertenecen a dicho Monte, como lo es la contribución ordinaria [...] pues es claro que debiendo pagar una parte de las contribuciones ya quieran o no gozar de sus beneficios, se decidirán mejor por lo primero»; AICAV, caja 388, junta de 30 de junio de 1836; libro 7, junta de 9 de noviembre de 1836; y libro 8, juntas de 22 de marzo o 18 de abril de 1828 .

18 TORMO CAMALlONGA, C., El Colegio de Abogados de Valencia. Entre el Antiguo Régimen y el Liberalismo, Valencia, 2004, pág. 151.

19 Así se lo comunica la Audiencia a Gregorio Genovés en 1834, ante su petición de recobrar las cantidades cotizadas. Genovés había argumentado en su favor que, en 1779, Blas Pons y Joaquín Salelles habían recobrado lo invertido después de que el Consejo les hubiese excluido del goce de las pensiones, por haber ingresado en el Montepío sólo cuando supieron de su enfermedad incurable. Pero ni la Audiencia ni el Consejo estimaron tal paralelismo. Genovés ya había intentado recuperar estas cantidades en abril de 1826, sin que la Junta accediera, por lo que decidió recurrir ante el Real Acuerdo. AICAV, libro 8, juntas de 29 de abril de 1826, 14 de febrero y 6 de marzo de 1827, 31 de octubre de 1833 y 13 de marzo de 1834, folios 181v, 186v, 187,209 y $211 \mathrm{v}$. 


\section{INGRESOS}

En el capítulo V, de los Fondos del Montepío, encontramos las tres únicas diferencias del reglamento valenciano frente al de Madrid. Las entradas en las arcas del Montepío eran las siguientes:

$1 .^{\text {a }}$ La cuota de ingreso, que ascendía a 1.500 reales vellón al contado en el momento de entrar en el Colegio y, consiguientemente, en el Montepío. En los asientos contables aparece para cada nuevo individuo un ingreso de 1.556 reales, pues a aquélla cifra se sumaban 40 reales de la tercia corriente de la contribución anual, 8 por los estatutos del Colegio y otros 8 por los del Montepío. El incremento respecto a la cuota anterior, de 900 reales y que se podía dividir en tres tercias, se quería acicate para la permanencia de los mutualistas en la sociedad.

2. ${ }^{\text {a }}$ La contribución ordinaria, de tres tercias anuales de 40 reales vellón cada una -80 en Madrid-, pagaderas a principios de enero, mayo y septiembre, aunque el tesorero las ingresaba en el arca de caudales a finales de abril, agosto y diciembre.

3. ${ }^{\text {a }}$ Por las conclusiones que cada individuo pusiera en los pleitos que defendiera, salvo en los de pobres, fueran para definitiva o para artículos o incidentes, contribuiría con 4 reales -en Madrid, $24{ }^{20}$. El 29 de abril de 1826 se sube esta cantidad a los 10 reales, no sin antes reconocer el incumplimiento generalizado de este arbitrio, «dejándose muchos acusar la rebeldía y volviendo los autos sin concluir». Se acordó conferenciar con el montepío de Madrid por ver si éste también exigía el papel con el sello del Colegio cuando se concluía para prueba, y representarlo al Acuerdo de Valencia para que dictase lo oportuno. El colegio matritense comunica que su práctica era "ponerlos en papel de conclusión resellado" por el colegio, refiriendo que los honores que devengaran en favor del letrado quedarían a beneficio del Montepío ${ }^{21}$.

20 En junta de 28 de abril de 1825 se acordó la formación del papel sellado, a imitación del de Madrid, para la conclusión de los pleitos. El expendedor de los sellos sería el asistente del Colegio, con la asignación del 3\% por razón de su trabajo. Sobre los escritos de conclusiones, véase TORMO CAMALLONGA, C., «El fin del Ius Commune: las alegaciones jurídicas en el juicio civil de la primera mitad del XIX», Anuario de Historia del Derecho Español, LXXI (2001), 473-500, pág. 480; «El abogado en el proceso y la argumentación en los informes jurídicos del XVIII», Ius Fugit. Revista de estudios histórico-jurídicos de la Corona de Aragón, 10-11 (2001-2003), 887-940; o "Un modelo en transición; práctica forense y legalismo decimonónico», RDUNED. Revista de Derecho de la UNED, 8 (2011), 477-513.

21 AICAV, libro 4, junta de 30 de mayo de 1826. 
Era el contador el que debía llevar la cuenta de este papel sellado. Con su media firma a un lado del sello del Colegio, los pasaba al tesorero para que pusiera la suya al otro lado, y los expidiera con la debida cuenta y razón de lo que debían producir. Este ingreso, gran novedad respecto al reglamento anterior, es un curioso ejemplo del tránsito de un sistema impositivo directo a otro indirecto, en el que se gravaban los beneficios obtenidos del ejercicio profesional. En principio, más contribuiría quien más beneficios tuviese, aunque las viudas cobrarían todas por igual.

4. ${ }^{\mathrm{a}}$ Por los honorarios de las cuentas y particiones de herencias y bienes en que intervinieran los abogados por nombramiento judicial, o de las partes por avenencia extrajudicial o por disposición de los testadores, se pagarían 30 reales vellón -en Madrid era la cuarta parte-. Es otro impuesto indirecto, con el inconveniente de que en ningún momento se establece medio de recaudación, de ahí su incumplimiento reiterado, como el anterior.

5. ${ }^{\mathrm{a}} \quad$ Los 160 reales en concepto del examen que se realizaba ante el Colegio para poder presentarse después ante el de la Audiencia -ante el Consejo en Madrid-, y que les daría derecho a examinarse hasta tres veces ${ }^{22}$. Otros tantos reales se pagarían si tuviesen que examinarse una cuarta vez. Es, sin duda, la principal y más exitosa novedad frente al anterior reglamento, pues contribuirían no solo los futuros colegiados, únicos que se beneficiarían en su momento, sino todos los abogados recibidos como tales, aunque no fueran a ejercer en la ciudad de Valencia.

6. ${ }^{\mathrm{a}}$ Ya hemos dicho que en junta de 11 de julio de 1825 se había desestimado el arbitrio del párrafo $6 .^{\circ}$ del capítulo V, relativo al ingreso de las tercias ordinarias devengadas a partir de los 26 años, y que afectaba a todos los que ingresaran superada esta edad, sin que estos pagos contasen como de residencia a efectos de cobro de pensiones. Pero, a pesar de que las actas no dejan constancia de que la Junta volviera a discutir sobre este extremo, sí se recoge a partir de las cuentas de 1832-1833, y de manera rigurosa. De hecho, en 1836 Nicolás Domínguez solicita el ingreso en el Colegio de una de estas dos maneras, a elección de su Junta: o bien pagando los 1.500 reales de vellón y renunciando a todo derecho del Montepío, o bien pagando las cantidades adeudadas por los 21 años que excedía desde

22 TORMO CAMALLONGA, C., «L'advocacia durant la vigència del pla d'estudis de 1824», Aulas y Saberes, 2 vols., Universitat de València, Valencia, 2003, II, págs. 619-628. 
la edad de 26 -2.520 reales en total-, a razón de cuotas atrasadas junto con cada una de las corrientes, de manera que pudiera pagar la totalidad de lo adeudado en el plazo máximo de cinco años. La Junta del Montepío desestimará ambas posibilidades por oponerse a la letra del párrafo 6. ${ }^{\circ}$. El 17 de junio la Audiencia solicita información del Colegio para evacuar el informe solicitado por el subsecretario de Gracia y Justicia sobre el caso, a raíz de la queja planteada por el mismo Domínguez ${ }^{23}$. El informe de la Junta vuelve a ser negativo, puesto que considera que lo único que pretende este sujeto es un trato excepcional e individualizado. Lo interesante de esta actitud es que va más allá de los simples intereses mutualistas, introduciendo la discusión sobre la legalidad y conveniencia de que la colegiación fuera requisito ineludible para el ejercicio de la abogacía. Finalmente, por orden de 6 de agosto de 1836 se manda estarse al plan propuesto por Domínguez, de ingresar en cinco años las cantidades debidas, con la condición de garantizar el pago por medio de hipoteca sobre una finca de su propiedad ${ }^{24}$.

7. ${ }^{\text {a }}$ El párrafo $7 .^{\circ}$ del mismo capítulo introducía la interesante consideración de que «en todos los establecimientos políticos son las penas pecuniarias uno de los medios o arbitrios de sostenerse». Desde esta concepción utilitarista de la pena, y vista la inoperancia del sistema de avisos, se estable un nuevo sistema de sanciones para los morosos, dependiendo de las tercias que adeudasen. Nadie podría ser tenido en demora hasta vencidas tres tercias y un mes más desde que principiare su adeudo, en cuyo caso purgaría la demora pagando un doblón más; si el atraso fuere de seis tercias y dos meses, debería pagar dos doblones; y si fuere de nueve tercias y tres meses, cuatro doblones, en cuyo defecto sería excluido irremisiblemente si en los ocho días después de su vencimiento no se pusiera al corriente. Lo curioso del caso, y para mayor escarmiento de los infractores que más tuviesen que perder, es que esta exclusión se aplicaría sólo cuando el individuo fuere casado o viudo con hijos con derecho a pensión, pues si fuere soltero o viudo sin hijos, la suspensión se entendería tan sólo hasta que pagase lo que tuviere vencido. Como medida persuasiva se castigaba más a aquellos con los que se asumían mayores obligaciones y

23 Parece ser que en esta petición anterior Nicolás Domínguez solicitaba que con sólo el ingreso de los 1.500 reales pudiese tener derecho a todas las pensiones, sin tener que pagar las cantidades devengadas desde los 26 años. En la siguiente petición ya vemos que modera sus pretensiones.

24 AICAV, caja 388, juntas de 20 de mayo, 30 de junio, 29 de agosto y 7 de septiembre de 1836, y 14 de octubre de 1841. 
más tenían que perder. Cierto es que no conocemos que se aplicara nunca esta disposición; es más, como en el anterior párrafo, es discutible su efectiva vigencia.

8. ${ }^{\mathrm{a}}$ Finalmente, el párrafo $5 .^{\circ}$ del capítulo X permitía a la Junta fijar nuevos arbitrios para sostener sus obligaciones, siempre que las circunstancias lo exigiesen. Es el caso del préstamo hipotecario con intereses del que se hizo uso frecuente en los últimos años, y en favor tanto de colegiados como de sujetos que no lo eran.

Podemos calificar la junta de 16 marzo de 1835 de inusual en cuanto que en ella se discutieron tres créditos. El primero en favor del colegiado Vicente Valor, de 8.000 reales vellón, para hacer frente a los gastos de su viaje a Mallorca, para cuya audiencia había sido nombrado oidor. La condición impuesta era su devolución en cuatro años al rédito del 3\%, anual, con la garantía hipotecaria de su casa. Acto continuo, el decano pide prestados, para sí mismo y bajo hipoteca, otros 20.000 reales, ofreciendo un rédito del 5\% anual y su devolución dentro de los seis meses siguientes al día que se le requiriese. El tratamiento que se le dispensa es diferente al anterior: el rédito es superior y, tal vez por ser mayor la cantidad, su aprobación se retrasó hasta el 28 de agosto, después de un examen exhaustivo de los títulos de las fincas ofrecidas. Trato similar fue el dispensado a José Sancho, suponemos que por su condición de no colegial. Para este hacendado que solicitaba 15.000 reales vellón, se manda que el tesorero estudiara los títulos de propiedad de la finca que presentaba como garantía, así como el rédito que se le debería imponer. Tras un exhaustivo informe, el 7 de abril se aprueba su concesión, al 5\% y con la condición, entre otras, de extender la hipoteca a un huerto adjunto a la finca ${ }^{25}$.

25 Otros casos, a título de ejemplo: el 26 de septiembre de 1835 se concedieron a Francisco Jaldero 35.000 reales, al 5\% de interés anual, bajo hipoteca sobre tierra en Aldaya. El 22 de marzo de 1836 el asistente del Colegio, José Domingo, solicita la cantidad de 300 libras hasta la recolección de la cosecha del arroz el día de Todos los Santos, bajo garantía hipotecaria de unas tierras en Sueca. La Junta accede, sin hablar del tipo de interés, bajo la condición de que el informe del tesorero fuera positivo. Extrañamente, en junta de 1 de mayo de 1837 Domingo desiste de la solicitud y se le devuelven los documentos. Pero también hay casos en que la Junta no accede, como creemos que sucedió con M. ${ }^{\text {a }}$ Tomasa de Villanueva. El 23 de julio de 1836 se estudia una petición suya de que «se le entregase en préstamo u a censo alguna cantidad baxo las garantías oportunas». Entendemos que la fórmula «téngase presente para quando se practique la liquidación de fondos», no es más que una negativa, pues no tenemos noticias de que se le concediera. 


\section{SOCORROS}

Frente al reglamento de 1778 , el de 1825 se presenta mucho más realista: más exigente en las contribuciones y menos generoso en las pensiones. Es significativo que, frente a la anterior regulación, concediera una clara preferencia a los propios individuos del Montepío sobre sus viudas y pupilos: según el capítulo $1 .^{\circ}$ "el objeto primero del establecimiento de este Monte Pío son los individuos del Colegio»; mientras que «el objeto segundo [...] son las Viudas», y «el objeto tercero son los Hijos e Hijas menores». Es una clara apuesta por la profesión frente a la compasión, que responde a ese cambio de mentalidad de origen ilustrado que se está operando, mayormente individualista y economicista. No obstante, creemos que hay otra razón, igualmente principal y mucho más pragmática, como era la de evitar a toda costa el fracaso en que incurriría de nuevo la sociedad si viudas y pupilos no veían rebajadas sus expectativas y derechos. La nueva concepción del mutualismo se enfrentaría, pues, con la mentalidad de los individuos que menos participaban en este cambio de rumbo, especialmente y por lo que veremos después, por lo que respectaba al trato que se concedía a las huérfanas.

Los riesgos que cubría el Montepío eran cuatro: invalidez permanente, incapacidad temporal, muerte, y viudedad y orfandad.

\section{Pensiones y socorros de abogados}

Disfrutarían de estos derechos aquellos individuos que, por edad avanzada o por enfermedad habitual o permanente con dictamen del médico y licencia del decano, no pudieran continuar en el despacho de los negocios y carecieran de otros medios de subsistencia. Este socorro se percibiría en cantidad variable, según el tiempo con que hubieran contribuido a las arcas; la misma de que gozarían, en su caso, las viudas, y que a continuación veremos. Ahora bien, si el abogado sanase y estuviese en condiciones de reintegrar lo que hubiese recibido, tendría la obligación de hacerlo, bajo sanción de descontárselo previamente y llegado el caso, a la viuda e hijos.

Si la enfermedad fuera transitoria, de nuevo con certificación médica y al entender del decano, y tampoco se disfrutara de otros arbitrios, el abogado tendría derecho a percibir, en concepto de incapacidad temporal, 30 reales diarios, con un máximo de 30 días si no 
falleciera antes. Estas cantidades debían ser reintegradas dentro del año inmediato a su restablecimiento. De no hacerlo, su viuda e hijos no gozarían de la pensión que les correspondiera llegado el caso, a menos que lo verificasen. Si la familia no contara con suficiente efectivo y el abogado dejare bienes, el Montepío se reservaba el derecho de interponer las acciones oportunas contra los mismos.

Finalmente, y en caso de muerte, si el abogado no dejase bienes con que costear su entierro, o no fuesen fácilmente convertibles, se le destinarían a tal efecto 1.200 reales, con idéntica calidad de reintegro que la arriba vista.

Significativo resulta que durante estos años no se concediera ninguna pensión por ninguno de estos tres conceptos. Lo que indica que el abogado no veía ninguna ventaja en percibir una cantidad, con valor de préstamo, que en todo caso tenía que devolver. Tampoco concedía la Junta limosnas. Apenas las había concedido con el anterior reglamento, y menos las iba a conceder ahora. En cualquier caso, era más oportuno plantearlas sobre los fondos del Colegio.

\section{Pensiones de viudas y pupilos}

Para el goce de la pensión de viudedad y orfandad, el abogado que ingresara en adelante debía haber contribuido al menos durante diez años cumplidos, pudiendo compensarlos anticipando al tiempo de su admisión los cuarenta doblones de las diez anualidades. Contribuidos los diez años, la pensión aumentaría en proporción a los años cotizados, "si lo permitieren los fondos del Monte Pío», en cuyo defecto se prorratearían en la medida de lo posible. Vista la experiencia, ya se contaba con la posibilidad de no poder hacer frente a las pensiones en su integridad, porque, a pesar de que esta pensión tendría consideración estatutaria de secundaria respecto a las de los letrados, continuará siendo la que más importaba a los abogados. De manera que el éxito de la sociedad dependería de la regulación de estos derechos.

El procedimiento para solicitar la protección se iniciaba cuando la viuda o pupilo con derecho presentaba ante la Junta el memorial de petición, en el que debía constar el día en que había fallecido el abogado, los hijos legítimos que dejaba, sus nombres, fes de bautismo, edades y situación, la fe de casamiento con la licencia otorgada por el decano, y la fe de defunción. Si el difunto dejare hijos pero no viuda, el memorial lo redactaría el tutor, curador, o cualquier otra 
persona. En todo caso, fallecido el individuo, el protector de viudas y pupilos debía ponerse a su disposición.

Hay que distinguir claramente entre las pensiones de las viudas y huérfanos que ya lo eran a la entrada en vigor del nuevo reglamento, de las que se constituirán en adelante. En ambos casos la filiación y el matrimonio debían ser legítimos. Hasta este punto no llegaba el carácter más secular de los montepíos ilustrados.

En cuanto a las pensiones que ya se cobraban en 1825, continuarían disfrutándose en la misma medida y circunstancias, tres reales diarios, dejando claro que «jamás podrán aspirar a mayor goce, por estar demostrado que las contribuciones que hicieron al Monte Pío sus maridos y padres no fueron suficientes para darles más derecho", además de que no habían tenido que cotizar un tiempo mínimo. Aunque las numerosas peticiones de mejora a las que sí tenían derecho las nuevas viudas se veían por aquéllas como privilegios discriminatorios, no era prudente atender más salidas de fondos que las estrictamente reglamentarias ${ }^{26}$. Además, a los huérfanos que ya cobraban pensión al tiempo de aprobarse el nuevo reglamento también se les mantenía en la antigua regulación, lo que era especialmente beneficioso para el caso de las hembras.

En cuanto a las viudas y huérfanos de los abogados que se incorporaban a partir de la entrada en vigor del nuevo reglamento, tendrían derecho a las mismas cantidades que los abogados con incapacidad permanente, y en la misma proporción según los años cotizados, a diferencia del primitivo reglamento, en que toda viuda y huérfanos tenían derecho a la misma pensión al margen del tiempo cotizado. Para poder cobrar ahora la pensión mínima, el difunto debía haber contribuido al menos durante 10 años, a no ser que hubiese anticipado 40 doblones. Si muriese antes y sin haberlos anticipado, las viudas «por el tiempo que falte para cumplirlos, deberán reintegrar la diferencia de treinta reales al mes, que media desde veinte reales que contribuyen todos, hasta cincuenta que se consideran como equivalentes de las otras contribuciones que hacen los que continúan egerciendo la abogacía ${ }^{27}$. A partir de los 10 años la cantidad a recibir aumentaría proporcionalmente a las cotizaciones. Si hubiesen cotizado de 10 a 16 años, recibirían 100

26 Es el caso de la viuda del abogado Pedro López, fallecido durante la vigencia del antiguo reglamento, y que en 1836 solicita aumento de la pensión. La Junta no accede a la petición aduciendo que carece de facultades para alterar el párrafo $1 .^{\circ}$ del capítulo III; AICAV, caja 388, junta de 2 de mayo de 1836.

27 No consta en los libros de actas que ninguna viuda se acogiera a esta posibilidad. 
ducados anuales; si hubiese cotizado de 16 a 24 años, 200 ducados; de 24 a 32 años, 300 ducados; y para los que hubiesen cotizado más de 32 años, la pensión sería de 10 reales diarios. Igualmente, si los fondos no permitiesen el pago completo de estas cantidades, «se prorratearán las que permitan los caudales, aumentando a los tres reales lo que corresponda a las clases referidas, con proporción al tiempo que hubieren contribuido sus maridos y padres». Esto es, la cantidad mínima a recibir y a mejorar sería la de tres reales diarios, que era lo mismo que cobraban viudas y pupilos que percibían pensión antes de 1825 .

El reglamento ya preveía que en el momento del fallecimiento algún abogado debiera alguna cuota de contribución anual. Si debía tres tercios, la viuda e hijos no tendrían derecho a la prorrata del tercio en que hubiese muerto, y el importe de aquéllos se descontaría de las primeras pensiones. Si hubiese quedado en descubierto en seis tercios o más, se haría el mismo descuento, al que se le añadirían los dos doblones de pena. Y si hubiese quedado en nueve tercios atrasados, viuda y pupilos quedarían sin pensión. Eran las propias viudas y huérfanos los que podían elegir entre satisfacer lo que el difunto había adeudado, o que se les descontase de las primeras pensiones.

Por otra parte, no tendrían derecho al aumento de los tres reales, las viudas e hijos de los individuos que hubiesen sido promovido a otros destinos, se hubiesen dedicado a otras actividades, o se hubiesen retirado de la abogacía, puesto que no soportarían las cargas del cuerpo ni podrían contribuir al Montepío con el honorario de las conclusiones, herencias y demás auxilios. Los colegiados que se encontraran en esta situación tendrían derecho a elegir entre abandonar el Montepío o permanecer en él. En este segundo caso optaban entre limitarse a pagar solamente la cuota ordinaria, que en su momento daría derecho al goce de la pensión mínima, o bien contribuir además con 528 reales anuales, a pagar por tercios, para poder percibir en su día los aumentos de pensión según el tiempo cotizado. La Junta no trató nunca sobre este párrafo, salvo en el caso planteado por Juan Inocencio Adell. Este abogado tenía un gran interés por demostrar que, aunque a la entrada en vigor del nuevo reglamento ocupaba el cargo de relator, lo había compatibilizado con la abogacía, que ejercía desde su ingreso en el Colegio en 1811, con lo que había contribuido al Montepío con todo ingreso que se exigía en cada momento, además de la contribución ordinaria. Como la compatibilidad entre la abogacía y la relatoría quedaba prohibida por el artículo 114 de las ordenanzas para las 
audiencias de 1836, solicitaba de la Junta que, reconociéndole los abonos efectuados hasta el momento, le permitiese contribuir en adelante al Montepío con la cantidad señalada para los no ejercientes. A lo que la Junta accedión ${ }^{28}$.

\section{Cese de la pensión de viudedad y orfandad}

La del fallecimiento no era la única causa de cese de la pensión. Las viudas, que gozarían ellas solas de la pensión completa una vez sus hijos perdiesen su derecho, la dejarían de percibir si profesaban en religión o contraían nuevo matrimonio. Para los hijos, se distingue entre varones y hembras. Los primeros tendrían derecho hasta los 17 años, si antes no profesaban o matrimoniaban. Como excepción, se les prorrogaría hasta los 21 si siguiesen carrera literaria o de armas y no obtuviesen antes sueldo ${ }^{29}$. El derecho de las hijas alcanzaba hasta los 25 años, salvo, igualmente, si ingresaban en religión o se casaban antes. Además, se les retendría el montante de las tres últimas anualidades para entregarlas en concepto de dote, al tiempo de casarse o de profesar. Como excepción, si «no hubiere esperanza racional de que pueda colocarse en alguno de estos estados la huérfana por impedida o deforme y carece de otros para su sustento a la calificación prudente de la Junta», se le conservaría la mitad de la pensión hasta su muerte. También cesaría la pensión si cualquiera de los hijos, varón o hembra, recibiese sueldo fijo de al menos 400 ducados anuales, beneficiándose de su parte, en su caso, los hermanos que quedasen.

Como bien recogía la letra del reglamento «en beneficio suyo y del Monte Pío», se estimulaba a las viudas sin hijos y huérfanas a dejar de percibir la pensión. En concepto de dote, se le concedería el importe de tres pensiones a la viuda que se casara o entrara en religión dentro de los tres primeros años de su viudez, y a la hija que fuera única si se casaba o profesaba antes de cumplir los 18 años.

Finalmente, y como sanción ante cualquier atentado contra el decoro que merecía el Colegio, la abogacía, los abogados, y especialmente sus difuntos padres y maridos, si el menor o la viuda con derecho a pensión no observaran la conducta «arreglada y corres-

28 AICAV, caja 388, junta de 15 de junio de 1836.

29 En junta de 3 de julio de 1834 se reconoce la pensión en favor de la viuda de Lorenzo Isern y de su hijo menor, y no a favor de los otros dos hijos, sordomudo el uno y cursante de Leyes el otro, por haber cumplido ambos los 21 años. 
pondiente», serían amonestados hasta dos veces en el intermedio de dos meses. De no surtir efecto la reprimenda, se les excluiría definitivamente del goce. Lo mismo si fuesen procesados criminalmente y sentenciados por delito considerado indecoroso. Y ello sin perjuicio de las demás providencias que conviniese.

\section{Huérfanas}

Por los datos de que disponemos, todo indica que vamos a asistir a una recuperación de los fondos del Montepío respecto al anterior periodo. Aun así, habrá momentos para la preocupación ante el siempre temible retraimiento de los colegiados. Y es bien probable que el motivo principal de la apatía que en algún momento se instaló, de nuevo, entre los colegiados, fuera el tratamiento que se dispensaba ahora a los pupilos, en concreto a las huérfanas ${ }^{30}$. Ya sabemos que con la anterior regulación los huérfanos tenían derecho a la pensión hasta que cumplían los 20 años; con la nueva, sólo hasta los 17. Las huérfanas, por su parte, tenían derecho hasta que tomaban estado, civil o religioso, o bien fallecían. Con el nuevo reglamento sólo hasta los 25 años, aunque no hubiesen tomado estado, reteniéndose las tres últimas anualidades para entregarlas por vía de dote al tiempo de casarse o profesar. Con el favor para ellas de que, más allá de los 25 años conservarían la mitad de la pensión hasta su fallecimiento, por vía de socorro, en el caso de que no hubiera esperanza racional de poderse casar o profesar. Esta última salvedad, sin embargo, no fue suficiente para calmar la inquietud de los abogados. El espíritu más liberal e individualista del nuevo reglamento chocaba frontalmente contra una sociedad no preparada todavía para romper con el tratamiento protector que secularmente se había concedido a las hijas. Frente a la utilidad solo privada que se pretendía de las nuevas sociedades, muchos todavía pensaban en ellas desde la perspectiva y satisfacción de las necesidades públicas. Una espinosa cuestión que había que resolver satisfactoriamente y lo más pronto posible.

El dilema se planteó, tempranamente, en abril de 1826. Los miembros de la Junta, partícipes de esta preocupación, decidieron esperar para ver la evolución de los fondos de la sociedad con la nue-

30 AICAV, caja 387, legajo sin número. Sobre la dote y la situación al efecto de las huérfanas en la idiosincrasia valenciana del Antiguo Régimen, dadas sus importantes implicaciones no solo personales y familiares sino también sociales, puede verse BAIXAULI JUAN, I. A., Casar-se a l'Antic Règim. Dona i família a la València del segle XVII, Universitat de València, 2003, págs. 53 y ss. 
va regulación. Ya hemos visto que se había acordado incrementar los fondos con un aumento de las conclusiones de los pleitos de cuatro a diez reales, al reconocer que no eran suficientes. La esperanza de bonanza inicial parece que empezaba a truncarse, lo que queda en evidencia cuando en junta de septiembre de ese año se designa una comisión para que investigase las modificaciones que pudieran realizarse en el Reglamento, tendentes a «fomentar la incorporación y sostener los derechos de los incorporados con arreglo al antiguo». De acuerdo con sus conclusiones, y por unanimidad de los miembros de la Junta, el 28 de octubre se solicita del Supremo Consejo la vuelta a la regulación anterior en cuanto a las pensiones a favor de hijas; que tuvieran derecho no sólo hasta los 25 años, sino hasta que tomasen estado, independientemente de su condición física ${ }^{31}$. En enero de 1828 la Junta da cuenta de la aceptación del Consejo, acordando se presentase la provisión ante la Audiencia para que diese cumplimiento y se circulase a los colegiales ${ }^{32}$. Sin embargo, no parece que la Junta tuviese ahora especial interés en el asunto, sabedora de que ello supondría un aumento de las cargas, aunque no fueran muchas las huérfanas implicadas; de hecho, el 20 de noviembre de 1834 se dice que todavía no se había presentado la provisión ante la Audiencia. Finalmente, 16 de marzo del año siguiente se recibe del Real Acuerdo dicho cumplimiento, para que todas las huérfanas continuaran con el goce de la pensión en los términos establecidos en el antiguo reglamento.

\section{LAS LAGUNAS DEL NUEVO REGLAMENTO}

Es cierto que los nuevos estatutos ofrecían mayor viabilidad de cobro a los mutualistas llegado el momento, pero también lo es que la penuria económica del Montepío había sido mucha y muy continuada en el tiempo. No podemos esperar que los abogados lo olvidaran fácilmente y depositaran ciegamente su confianza en la nueva regulación. Persistía la incertidumbre y surgían nuevas dudas, máxime cuando la Junta se mostraba indecisa ante cada nueva contrariedad. Al menos, así lo percibían los individuos. Al tema de las huérfanas se añadía el que los estatutos contenían algunas lagunas significativas, que se resolverían por la Junta o los tribunales,

31 En juntas de 4 y 24 de enero de 1827 vemos cómo la Junta informa a la audiencia de Valencia, en relación al informe que al respecto le había solicitado el Consejo. Por junta de 7 de marzo sabemos que el Consejo también solicitó informe del colegio de abogados de Madrid.

32 AICAV, libro 8, folios 181v, 184v, 185, 185v, 186, 186v, 187v y 191. 
según se materializaban. Pero a los abogados las soluciones dadas no siempre les resultaban convincentes, ni siempre las veían coherentes.

El mayor problema era resolver si la regla de los diez años de cotización exigidos para el cobro de la pensión afectaba a todos los abogados o sólo a los que ingresaban en el Montepío una vez aprobados los nuevos estatutos. Sobre lo que ocurría con los que habían empezado a cotizar antes de 1825 la respuesta difería entre los que en ese año ya habían contribuido con, al menos, diez años, de los que no.

En el primer supuesto encontramos a la viuda e hijas de José Antonio Sombiela, fallecido en $1826^{33}$. El Real Acuerdo les reconoce pensión con arreglo a los nuevos estatutos y, por lo tanto, en la cantidad asignada al número de años cotizados — que superaban los diez-, y ello a pesar de que dichos años se cotizaron vigentes los estatutos de 1778 y con aquellas cantidades. Con esta decisión, la Audiencia corregía a la Junta del Montepío que denegaba la pensión según el párrafo 9. ${ }^{\circ}$ del capítulo $\mathrm{V}$, al haber quedado el difunto adeudando el día de su fallecimiento más de tres años. Si la Junta se centraba en la morosidad, la Audiencia hacía prevalecer el número de años cotizados, obligando a los beneficiarios, eso sí, a satisfacer las cantidades adeudadas. La Junta, disconforme con la resolución, recurre ante el Consejo, aunque las actas ya no refieren cómo se resolvió el recurso.

El segundo supuesto se platea por primera vez en 1829 . Se discute si los abogados contribuyentes en el momento de aprobarse el nuevo reglamento perdían la antigüedad, o bien conservaban los años cotizados para sumarlos a los que iban a cotizar con las nuevas condiciones, y cobrar así la pensión según la nueva regulación. Y esta discusión tiene lugar a pesar de la manifestación del Real Acuerdo vista en el párrafo anterior. Es por estas situaciones de inseguridad que persiste la suspicacia de los letrados. Se consulta al colegio de Madrid, por esto y también por saber si «a los antiguos que no pagaban se les hizo alguna invitación por si querían continuar en dicho Montepío» ${ }^{34}$. Parece que la Junta pretendía conceder alguna

33 AICAV, libro 8, juntas de 26 de junio, 14 de julio y 8 de agosto de 1826, 14 de febrero, 6 y 7 de marzo, 25 de abril, 14 de mayo, 9 de junio y 15 de octubre de 1827 .

34 La trascendencia de la duda se evidencia en la convocatoria de los consiliarios. Se trata de un cargo que no formaba parte de las juntas, ni del Colegio ni del Montepío, a los que se convocaba sólo cuando la relevancia de los asuntos a tratar lo requería; Tormo Camallonga, C., El Colegio de Abogados..., pág. 91. 
deferencia a los que contribuían al tiempo de aprobarse el nuevo reglamento. El problema era concretarlo.

En 1830 se vuelve a discutir este asunto y sobre el tipo de admisión de los que pretendían incorporarse en adelante. Dos eran las posturas planteadas. El tesorero defendía que para el aumento de la pensión se les computase únicamente los años cotizados desde la entrada en vigor del nuevo reglamento, mientras que el contador opinaba que el cómputo debía entenderse con inclusión de toda su antigüedad. La Junta, finalmente, acuerda atenerse al nuevo reglamento, «rigurosamente sin novedad ni interpretación alguna, asignándose las pensiones con proporción al número de años de incorporación de cada individuo». Por lo tanto, computando la totalidad de años ${ }^{35}$. Es la solución más coherente con la resolución de la Audiencia vista arriba, y que vemos reiterarse en 1833 cuando Juan Inocencio Adell solicita de la Junta declaración sobre si, llegado el caso, le corresponderían a él, su viuda e hijos, los 9 reales diarios del reglamento antiguo, o la pensión y demás prerrogativas de los nuevos estatutos. Sin discusión alguna ahora, la Junta contestó que, al estar abolido el reglamento de 1778, le correspondería lo fijado en el nuevo ${ }^{36}$.

Paralelamente a este segundo supuesto, se plantea la cuestión de saber qué ocurría con los que, habiendo empezado a cotizar antes de 1825, no cumplían los 10 años a tiempo de su fallecimiento. En 1830 se le niega la pensión a la viuda de Luis Pasqual y Marqués, por no llevar contribuidos dichos años ni haber anticipado al tiempo de su admisión los 20 doblones. También es el caso de la viuda de Juan Bautista Alberola, visto en 1835. Este abogado había ingresado en el Montepío el 2 de diciembre de 1824, y había muerto el 3 de noviembre de 1834, es decir, sin haber cumplido los 10 años exactos exigidos. Dos son las conclusiones que se extraen del proceder de la Junta en estos casos. Por una parte, que, aunque «debería declararse sin derecho», se podía superar este contratiempo «bien meditadas las mismas palabras del reglamento», es decir, interpretando no que «sus maridos hubiesen vivido diez años completos incorporados en el Monte Pío, sino que hayan sido contribuyentes de diez años completos». Y, puesto que había pagado la última tercia de septiembre, la Junta reconoce el derecho de la viuda al goce de los 100 ducados

35 En la siguiente junta se le concede a Rita Gramage, viuda de Francisco Calvo, la pensión de 200 ducados, por pasar de los 16 años la cotización de su marido; AICAV, libro 8 , folio 201v.

36 AICAV, libro 8, junta de 11 de abril de 1833, folio 208v. Véanse también folios 214 y $215 \mathrm{v}$.

(C) UNED. Revista de Derecho UNED, núm. 12, 2013 
de pensión ${ }^{37}$. Por otra parte, tanto el reglamento como la Junta, cuando se refieren a este asunto hablan de los abogados que «en adelante se incorporen» al Montepío, es decir, después de su aprobación en 1825, lo que, en principio, no debería haber afectado a los que, como éste, ingresaron con anterioridad. Esto último, sin embargo, no parece ser muy coherente con las resoluciones de los casos anteriores.

Es obvio el interés de la Junta por resolver todos estos problemas de manera más o menos coherente y, en la medida de lo posible, en favor de los individuos afectados. Pero cada discusión se tornaba en duda e inquietud para los abogados, que permanentemente veían motivos para la desconfianza.

\section{EVENTUAL EQUILIBRIO PRESUPUESTARIO}

A falta de manifestaciones de la Junta, aportaré una serie de indicios que nos hacen pensar que, a pesar de las dudas, recelos e incertidumbres, la situación económica del Montepío mejoró ostensiblemente con la nueva regulación. Aunque la realidad nunca permitió bajar la guardia, podemos afirmar que no se repetiría la calamitosa situación vivida bajo el anterior reglamento. Prueba de ello es que en ningún momento se retrasa el pago a las viudas ni se reduce la cuantía de las pensiones, cosa más que frecuente en los años anteriores $^{38}$. No podía ser de otra manera dado el nuevo y muy productivo sistema de ingresos por las cuotas de entrada y de recibimiento de abogado ante la Audiencia, esta última tasa inexistente con anterioridad, y que en algunos ejercicios supuso hasta una cuarta parte del total de ingresos.

Los colegiados recibieron con agrado la nueva normativa desde el primer momento. Durante los años inmediatos a su aprobación, muchos de ellos pactaron con la Junta planes particulares para actualizar sus pagos atrasados; planes que el secretario redactaba después de estudiar la liquidación para cada uno de ellos, lo que se reducía, por lo general, a ir pagando junto con cada cuota vencida

37 En junta de 16 de septiembre de 1837 se desestima la solicitud de pensión de la viuda María Teresa Samper por no haber llegado a contribuir su marido los 10 años; había ingresado el 7 de agosto de 1838.

38 En algún caso, y a solicitud de la viuda, incluso se adelanta el libramiento de la pensión. No obstante, es una práctica que ya se observaba con el antiguo reglamento, especialmente para Navidad. La junta de 31 de agosto de 1838 rechazaba el adelantamiento de toda una anualidad, no porque no hubiera fondos, sino porque estaba en curso la redacción de un nuevo reglamento. 
otra atrasada. En otros casos se acordaba abonar todas las cuotas atrasadas en una o dos tandas. Siempre con la condición de que los beneficiarios no tendrían derecho a ninguna de las pensiones hasta haberse puesto al día con todos los atrasos. Salvo casos puntuales, la Junta se mostrará muy rigurosa en la fiscalización de los pagos. Obviamente, y en paralelo a la recuperación de los fondos, también aumentó el interés de cobro por las viudas. Síntoma de la esperanza en los nuevos estatutos, es la pronta decisión de 16 de septiembre de 1826, de expedir a las viudas y pupilos, desde las navidades venideras, 100 ducados anuales, "con arreglo a lo establecido en el nuevo reglamento, mediante a que es de esperar que los nuevos arbitrios facilitarán fondos suficientes para seguir el pago de las asignaciones según el mismo reglamento» ${ }^{39}$.

Otro síntoma de bonanza es la junta de 21 de julio de 1827, en que, haciéndose eco de los ingresos rezagados, y «conociendo al propio tiempo lo beneficioso que es el que los colegiales antiguos que quieran continuar con obción al Monte paguen los atrasos y que esto se haga demostrable», se aprobaba una reestructuración de los fondos, con el propósito de evitar la incertidumbre en que se había movido la Junta durante los años anteriores. Se aceptaba así la iniciativa del diputado cuarto, que el 24 de enero ya había indicado la conveniencia de hacer un recuento formal de todos los fondos del arca, tanto en metálico como en «vales de cautelas de intereses». A partir de ahora, se llevarán tres contabilidades, con sus propios libros de tesorería, secretaría y contaduría. Una del fondo corriente, donde debía recogerse la recaudación anual y los sobrantes después de satisfechas las cargas. Otra del fondo de atrasos, con los ingresos de los individuos que, estando atrasados, manifestaban su deseo de continuar, pagando los atrasos, y si así lo hubiese aceptado la Junta. Y la tercera contabilidad para los fondos de la administración de los bienes de doña Cecilia Barber ${ }^{40}$. Todos los fondos continuarían en el arca única de caudales con tres llaves, en posesión cada una de ellas del decano, contador y tesorero, y custodiada en casa de este último. De manera que para cualquier introducción, extracción o recuento

\footnotetext{
39 AICAV, libro 8, folio 185v.

40 Inmuebles situados en la ciudad de Valencia y su huerta, que en 1789 habían sido otorgados en escritura a favor del Montepío por el colegiado Vicente de Alagón, como único ejecutor de la última voluntad de esta señora; TORMO CAMALLONGA, C., «El Montepío del Colegio..., pág. 51. La contabilidad de esta herencia fue, posiblemente, la que más quebraderos de cabeza ocasionó, sobre todo por los problemas con los herederos de Juan Antonio Pérez Clemente, en cuanto que a la Junta no le satisfacía las cuentas que éste había presentado en su momento como administrador de los bienes; AICAV, libro 8, juntas de 20 de octubre y 11 de noviembre de 1826.
} 
de caudales, debían asistir necesariamente los tres individuos o, en caso de ausencia, las personas que designaran. A finales de abril, agosto y diciembre se harían las entradas que aprontara el tesorero, quedando en su poder sólo las cantidades precisas para pagar el tercio de las pensiones que vencían en ese tiempo, más alguna cantidad menor para hacer frente a imprevistos.

Otro ejemplo que nos hace pensar en la bonanza económica de la sociedad es lo ocurrido con el abogado Gaspar Monleón. En el momento de su muerte, a manos de los carlistas en 1836, sólo había contribuido ocho años. Atendido el contexto, y por las especiales circunstancias dadas en su ingreso en el Colegio, la Junta le reconoció a su viuda el goce de la pensión, previo ingreso de las cantidades adeudadas. Monleón había solicitado el ingreso en 1822 , que no pudo verificarse porque los abogados informantes se negaron a recibir la sumaria de limpieza de sangre que los estatutos exigían, al considerar que estas pruebas eran contrarias al régimen constitucional entonces vigente. Aún así, Monleón consiguió habilitación de la Audiencia para ejercer, aunque no consiguiera colegiarse hasta 1828. Entendiendo la Junta que el retraso en su incorporación y cotización no le era imputable, accedió a conceder la pensión. Además, el Montepío acataba así «los deseos del gobierno de que se dé alguna recompensa a las viudas de los que mueran en su defensa ${ }^{41}$.

Pero también tenemos alguna manifestación de la Junta en el sentido de que esta situación de bonanza podía ser solo relativa y precaria. Ya hemos visto cómo con el tema de las pensiones de las huérfanas, en 1826 se forma una comisión para estudiar las modificaciones reglamentarias oportunas, como así se consiguióo ${ }^{42}$. Otro indicio de que los fondos del Montepío no iban sobrados lo tenemos cuando en enero de 1832 el tesorero comunica a la Junta no tener efectivo suficiente para atender las pensiones de viudedad, acordándose su extracción del arca. Pero pocos indicios más podríamos aportar en este sentido.

41 Con los estatutos del Colegio de 1762, todo abogado que quisiera ingresar en la corporación debía acreditar, mediante memorial redactado al efecto y entre otros extremos, ser de buena vida y costumbres, hijo legítimo y que, así el pretendiente como su padre y abuelos fueran cristianos viejos, sin nota alguna de moros, judíos o recién convertidos a la fe católica; también que ninguno de ellos tuviera o hubiera tenido oficio vil o mecánico. TORMO CAMALLONGA, C., El Colegio de Abogados..., págs. 344 ss. AICAV, caja 388, juntas de 30 de junio, 29 de agosto y 21 de diciembre de 1836.

42 AICAV, libro 8, junta de 23 de septiembre, folio $184 \mathrm{v}$. 
LA PRECARIEDAD EN SU VOLUNTARIEDAD: LAS SOCIEDADES DE SOCORROS...

CUENTAS*

\begin{tabular}{|c|c|c|c|}
\hline Ejercicios & Cargo & Data & Alcance \\
\hline $1825-26$ & $44.163,22$ & $37.089,11$ & $7.074,11$ \\
\hline $1826-27$ & $40.649,26$ & $21.752,15$ & $18.897,11$ \\
\hline $1827-28$ & $42.013,29$ & $42.013,29$ & - \\
\hline $1828-29$ & $56.580,90$ & $56.580,90$ & - \\
\hline $1829-30$ & $30.930,30$ & $30.930,30$ & - \\
\hline $1830-31$ & 30.923 .30 & $27.493,40$ & $3.430,26$ \\
\hline 1831-32 & $28.037,22$ & $20.629,11$ & $7.408,70$ \\
\hline $1832-33$ & $80.970,29$ & $58.477,28$ & $22.493,10$ \\
\hline $1833-34$ & $51.617,30$ & $51.617,30$ & - \\
\hline $1834-35$ & $71.046,20$ & $43.592,29$ & $27.453,25$ \\
\hline $1835-36$ & $69.842,11$ & $33.972,23$ & $35.869,22$ \\
\hline $1836-37$ & $73.197,20$ & $35.662,30$ & $37.534,33$ \\
\hline $1837-38$ & $70.586,25$ & $55.810,25$ & $14.776,40$ \\
\hline 1839 & $41.495,20$ & $35.617,28$ & $5.877,80$ \\
\hline 1840 & $81.287,90$ & $33.693,13$ & $47.593,30$ \\
\hline $1841-1846$ & $89.741,26$ & $63.241,25$ & $26.500,10$ \\
\hline
\end{tabular}

* En reales vellón y maravedíes. Fuentes: AICAV, Libro de Acuerdos de la Junta del Montepío, y Actas de las Juntas del Monte Pío, libro 8 y cajas 388 y 398-401.

\section{CONSIDERACIONES FINALES}

La aplicación de los estatutos de 1825 muestra el escepticismo y la vacilación de los mutualistas y la junta del Montepío en la confianza e interpretación de su articulado. Esta última se imponía restrictiva, dado el fracaso de la anterior regulación, tan poco realista. Además, lo exigirá la nueva ideología liberal, que, en principio, no estaba en el origen ni en las pretensiones del nuevo reglamento, tributario por igual de la concepción fraternal que inspiró su fundación pero también de la imperiosa necesidad de sanear sus fondos. Pero esta nueva regulación tampoco será capaz de ofrecer respuestas inequívo- 
cas en la medida en que la nueva filosofía individualista del naciente liberalismo, que de alguna manera ya se estaba abriendo paso durante estos años, estaba lejos de las formas y querencias de algunos abogados todavía anclados en pretéritas estructuras y convicciones. La Junta, además, seguirá sin tener poderes plenos para dirigir la sociedad en la medida en que el Supremo Consejo y la Audiencia todavía tendrán un importante papel de gendarme y poder de decisión. Un escenario de tránsito entre dos concepciones del corporativismo y sus relaciones con la Administración y los nacientes derechos individuales. Fueron, sin duda, unos estatutos interinos.

Es cierto que pecuniariamente se recomponen los fondos del Montepío, pero no lo es menos que esta mejoría difícilmente podría resultar sólida y definitiva. Los abogados que ingresaran en el Colegio a partir de 1825, cuya adscripción a la mutualidad era obligatoria, tenían que cotizar al menos diez años para tener derecho a los beneficios más abultados, con lo que durante estos primeros años son muchas más las entradas que las salidas. Los antiguos estatutos habían demostrado que se podían asumir necesidades medianamente transitorias, pero no permanentes, como la invalidez absoluta o la viudedad. Así es que la nueva regulación imposibilitaba que un abogado que moría al poco de ingresar en el Montepío, agraciara a su viuda e hijos con una pensión para el resto de sus días, cosa que sí podía suceder, y de hecho sucedió, en tiempos de los antiguos estatutos, en que, sin apenas cotización, la sociedad debía correr con unas pensiones que desequilibraban completamente sus fondos. Por esta parte se ganaba en confianza hacia los abogados, y así fueron muchos los que consideraron positiva su permanencia en la sociedad. Si en la lista de 1824 tan sólo 9 de los 115 colegiados podían considerarse miembros de hecho del Montepío, o sea, el $7.82 \%$, en la de 1835 serán 100 de 161 , el 62.11\%. Consecuentemente, y con el tiempo, se concederán las oportunas pensiones. Y si la Junta decidió la continuidad de la sociedad más allá de los Estatutos para los Colegios de Abogados, de 1838, a pesar de que su artículo 36 declaraba abolidos los montepíos forzosos, lo fue por la estimable función social que algunos abogados veían en ella y porque juzgaba que, con los estatutos de 1825, "se elevó a su mayor grado de prosperidad» ${ }^{43}$.

43 El referido artículo decía: «Habiendo cesado de hecho los antiguos Montepíos forzosos, en virtud del decreto de las Cortes de 8 de Julio de 1837, las personas que tenían adquirido derecho a los fondos existentes, se entenderán con los Colegios respectivos y arreglarán entre sí o propondrán los medios que crean más a propósito para que no se cause perjuicio»; MARTÍNEZ ALCUBILLA, M., Diccionario de la Administración Española, 8 vols., Madrid, 1886-1887, I, p. 60. Por un documento del Colegio de Abogados de 31 de mayo de 1845, remitido al Ministerio de Justicia, 
Pero, con los nuevos Estatutos, el Montepío vería gravemente alterado no ya su régimen, sino su propia subsistencia.

Por estos años se está impulsando la implantación de un nuevo régimen económico necesitado de grandes inversiones. A nuestros efectos, alguna de sus derivaciones se va a imponer a una realidad práctica que, aunque con dificultades, hemos visto que podía funcionar más o menos satisfactoriamente. Si el reglamento de 1778 fracasó en su momento por falta de suficiente previsión, el de 1825 fue inhabilitado desde el gobierno antes de fracasar, por razones diferentes, de las que ahora sólo ofreceremos unas muy simples pinceladas ${ }^{44}$.

El 24 de junio de 1838 se celebra junta general del Colegio en donde se acuerda que continuara la del Montepío. Se designa una comisión para la redacción de un proyecto de nuevo reglamento que vendría presidido, obviamente, por la omnipresente voluntariedad o libertad de que hablaba el decreto de 11 de julio de 1837 . Pero este nuevo reglamento finalmente no se materializará. Por real orden de 18 de febrero de 1839 se admitía la constitución de sociedades mutualistas. Y utilizamos el verbo admitir como contrapeso a la férrea política antigremial del momento. Como podemos imaginar, la incertidumbre ante el futuro pesaría más que el empeño de algunos individuos. Por junta general de 26 de septiembre de 1841, y en aplicación del artículo 36 de los Estatutos, se reconoce a todo contribuyente el derecho a abandonar la sociedad cuando así lo decidiera, con la devolución de las cantidades que hubiera ingresado, para lo que el 14 de octubre se acordaba nombrar comisión que practicase las correspondientes liquidaciones. Aunque la realidad de los hechos no respaldaba de manera inequívoca decisión en ninguno de los sentidos, no hay duda de que el contexto económico-legal, en el que no primaba precisamente el principio de solidaridad, no resultaba nada favorable al mutualismo, por mucha función social que cumpliera. Y así parece que lo sintieron la mayoría de asociados.

Debemos traer a colación la importante obra legislativa española del momento sobre instituciones financieras $\mathrm{y}$, destacadamente, el nacimiento de las cajas de ahorros, que se reconocen, desde el respaldo doctrinal de las sociedades económicas de amigos del país, por las reales órdenes de 3 de abril de 1835 y, destacadamente y dado el

sabemos que al tiempo de la extinción de facto del Montepío a principios de 1841, se estaba proveyendo la subsistencia de " 15 viudas o huérfanas»; Archivo General del Ministerio de Justicia (en adelante, AGMJ), caja 300-1, legajo 197.

44 La incompleta y deficiente documentación sobre estos años no permite aventurar conclusiones más concretas. Véase NÁCHER HERNÁNDEZ, P., Historia del Ilustre Colegio de Abogados de Valencia, Valencia, 1962, págs. 237 y ss. 
previsible éxito de la de Madrid, por la de 17 de abril de 1839, que disponía la creación de una de ellas en cada provincia. Constituidas como entidades privadas sin ánimo de lucro, y en pugna contra cualquier tipo de usura, las reglas de juego del momento, sin embargo, estaban más próximas al capitalismo liberal y a la voluntad de desarrollo de un moderno sistema crediticio que pudiera hacer frente a los retos que planteaba la incipiente industrialización del país, considerando también la ineficacia y escasa fiabilidad del naciente modelo bancario. Así pues, se pretende en ellas que al cálculo benéfico propio de todo montepío se uniera también el financiero, que, claro está, podía resultar más atractivo para los colegiales, en la medida en que los fondos podrían proporcionar mayor seguridad no solo en el capital sino también en intereses. Y, obviamente, resultaba más beneficioso para la economía nacional. Por muy abstencionista que se proclamara el régimen liberal, debemos tener presente la voluntad de las cortes y de todo gobierno de procurar una nueva regulación económica y social desde la tutela central y unificada de todas las instituciones. Frente a la autonomía corporativa proclamada, no desaparece el intervencionismo estatal.

Claramente, este escenario de incertidumbre económico-financiera y asociativa tendría su traducción en los fondos del Montepío. Con ocasión de la tercia de Navidad de 1839 se hace saber que en poder del tesorero obraban 7.636,23 reales, mientras que el pago ascendía a 10.622,23. Ante la imposibilidad de obtener dinero por otras vías, se acuerda en junta tomar 3.000 reales del fondo de la administración de los bienes de Cecilia Barber en calidad de reintegro. El déficit se extiende al pago de la primera tercia de 1840, con lo que en abril se acuerda de nuevo extraer del mismo fondo 6.000 reales, también en calidad de reintegro, normalizándose la situación para la segunda y la tercera tercias. Es más, con la devolución a principios de 1841 de dos antiguos préstamos, se dispone de liquidez suficiente para reintegrar las cantidades sustraídas de aquella administración. Así pues, los libros del Montepío no ofrecen cuentas para que, desde una perspectiva estrictamente economicista, se justificaran medidas como las que, en pro de la libertad individual, se estaban tomando desde el gobierno.

Definitivamente, por un escrito de 26 de abril de 1848 sabemos que en junta de 8 del mismo mes se dejaba constancia de que el 3 de diciembre de 1844 se había practicado la liquidación de los fondos del Montepío, y de que el 12 de diciembre de 1847 se había acordado que los interesados podían retirar todo lo invertido para después, si era esa su voluntad, retornar al nuevo Montepío que algunos individuos 
querían fundar ${ }^{45}$. Pero no cuajó el intento, partiendo de que su carácter estrictamente voluntario le convertiría en «eventual y precario en su esencia misma». Aun así, remitieron al Ministerio de Justicia un proyecto de estatutos de 63 artículos sobre la base de los de $1825^{46}$.

El 13 de diciembre de 1848 el tesorero hace presente que la cantidad reservada para las limosnas de Navidad era la misma desde años atrás, y muy escasa, dado el gran aumento de incorporaciones que se había producido en el Colegio, y el consiguiente mayor número de viudas y huérfanos. Además, «con la supresión del Montepío y distribución de los fondos que el mismo tenía habían cesado las pensiones que a aquéllos se daban, no habiendo probabilidad de que se restableciera este establecimiento, visto que habían sido inútiles los esfuerzos que hicieron para ello el Colegio». Es decir, que desde hacía varios años el Colegio sólo contaba para socorrer los menesteres de sus individuos, vía limosna, con los fondos de la administración de los bienes de Cecilia Barber, y que se mantendrán a lo largo de las siguientes décadas. La actividad del Montepío en estos momentos era prácticamente nula, limitándose a aprobar las cuentas de los fondos de estos bienes ${ }^{47}$. A partir de ahora se hablará de la Junta del Antiguo Montepío.

La nueva administración liberal no estaba dispuesta a dejar caer a los colegios de abogados, pero no tenía inconveniente alguno en hacer lo propio con sus montepíos o sociedades de socorros mutuos. Desde el todopoderoso dogma de la libertad individual se sacrificaba una corporación que, con sus carencias e irregularidades, podía atender a ciertas necesidades sociales, en favor de una ideología claramente voluntarista de forma y monetarista de fondo. Lo cierto es que la desaparición del Montepío no respondía a una demanda de los abogados, como muchos sí habían querido para el Colegio, sino, simplemente, a los propósitos de la nueva ideología económico-liberal.

45 En estos momentos resultaron 161 abogados partícipes y 19 pensionistas; NÁCHER HERNÁNDEZ, P., Historia del Ilustre Colegio..., pág. 252.

46 AGMJ, caja 300-1, legajos 197.

47 En junta de 15 de diciembre de 1851 se solicita un crédito de los fondos de doña Cecilia Barber. Véase otro crédito en junta de 25 de septiembre de 1855. Es más, de finales de 1852 nos consta una solicitud de aprobación de los estatutos de un nuevo Montepío en la que se parte de la contundente consideración siguiente: «comprende igualmente el Colegio, experimentado ya con el egemplo palpitante de las nuevas asociaciones, que no es posible tener lo que desea y tanto necesita»; AGMJ, caja 300-1, legajos 197. 
